\title{
DEVELOPMENT OF READING COMPREHENSION WITH GRAPHIC ORGANIZERS FOR STUDENTS WITH DYSLEXIA
}

\author{
Jacqueline Lopez $\left(\mathbb{D}\right.$, Johnny Campoverde ${ }^{i D}$ \\ University of Guayaquil (Ecuador) \\ jackielopez_@yahoo.com,bjobnsy@icloud.com
}

Received February 2018

Accepted March 2018

\section{Abstract}

This academic work has the aim of analyzing the impact of graphic organizers in the development of reading comprehension accordance with the level of English of each student. The theoretical foundation is constructed by the contents previously defined in the problem; with specific bibliography for the scientific content. Statistical analyses of information were taken into consideration. The implementation of this research will permit the creation and design of a handbook with easy-to-read stories that would increase students receptive abilities in a foreign language in the learning process, especially for students with learning disabilities (dyslexia). These analyses determined the importance of the application of a handbook that would include a short and a long text, vocabulary in context, strategies to improve reading skills, and unit assessments to evaluate the knowledge of students in each unit. This will let the students to develop multiple skills with the guidance of the teacher. This innovative material has as a main target to help the learner to decode phonemes and to identify structures of the story through charts and pictures.

Keywords - Dyslexia, Reading Comprehension, Graphic Organizers.

\section{Introduction}

When students are learning a foreign language like English, one of the skills to develop is Reading Comprehension. If students do not understand well the content of the reading it would be difficult for them to grow in the learning process of the new language. The development of reading comprehension becomes harder when the students show a difficulty in the knowledge apprehension which can be appreciated as learning disabilities and involve some negative aspects in students who have the principal role in the learning process.

In Ecuadorian Public Institutes is not very common to observe children with this kind of problems, but exists a few cases, consequently it does not mean that Ecuador does not present students with learning disabilities by the contrary it presents some cases that need to be attended. However, the fact is that the Ecuadorian Schools do not have trained teachers that can help learners with their disabilities or maybe teachers do not know or they are just not interested in this theme and for that reason it is so important to extend the investigation about these Learning difficulties in order to help students while they are learning another language.

If the students do not own competent reading comprehension skills to perform what the teacher requires, it will become harder to understand the content of the reading and without comprehension students get confused and cannot work in any activity. Reading is not only a simple action of observing words from one side to the other while making them sound, and it becomes worse if the students are not really focusing on what the page says it has no connotation. There are various purposes for what people read, however the main target is to obtain some 
apprehension of what the author tries to transmit and use the gathered information. This is the reason that makes reading comprehension skills very substantial. The lack of this ability does not let the reader to assemble data and employ it in a proficient aim.

The absence of the use of adequate resources, unable the students to learn and apply the correct analysis, interpretation, relation, and identification of messages in the readings of English texts, consequently the objective of this investigation is to analyze the impact of graphic organizers in the reading comprehension of students with learning disabilities through a bibliographic study, a statistic and field analysis, to design a handbook with easy-to-read stories, based in the essential fundamentals: Epistemological, Pedagogical, Psychological and Legal.

One of the principal difficulties in the learning that the actual society faces is the lack of comprehension of reading, because it is what gets confused to read in spite of understanding the contents. Cain and Oakhill (2004) state that "Reading comprehension clearly involves more than the simply accessing the meaning of the individual words in the text" (2004: page 51). In other words, students do not own competent reading comprehension skills to perform what the teacher requires them to do in a systematic way. Without comprehension, reading is only a simple action of observing words from one side to the other while making them sound, but the students are not really focusing on what the page says it has no connotation.

Some factors that influence the learning process of students with disabilities as Dyslexia are the lack of trained teachers with an adequate ESL methodology, the absence of the use of graphic organizers to improve reading skills, and the need of suitable resources for students with learning disabilities.

According to Gina Kemp, M.A., Melinda Smith, M.A., and Jeanne Segal, Ph.D. Last updated: December (2017), "There are two types of learning disabilities in reading. Basic reading problems occur when there is difficulty understanding the relationship between sounds, letters and words. Reading comprehension problems occur when there is an inability to grasp the meaning of words, phrases, and paragraphs." Reading is arguably the most difficult skill to be developed, especially for students with learning disabilities. One of the most common problems for ESL (English as a Second Language) students is Decoding Difficulties. ESL students cannot decode phonemes and separate them from the sounds; this difficulty frustrates students because they have problems in pronouncing the words and identifying the sounds. By not being able to pronounce words properly, they do not read with expression and they ignore punctuation. Decoding Difficulties is also linked to students with Dyslexia.

At the present time, it can be observed that there are a lot of people with both physical and mental or sensory worldwide disabilities, this figure can be uncountable but it is in sight of the human beings, it is common to find people with inabilities at home, at work and the most frequent place is at school, even in developed countries. But unfortunately, in many cases these people are marginalized by the society which they belong.

LDAC (2015) asserts that "Learning Disabilities refer to a number of disorders which affect the acquisition, organization, retention, understanding or use of verbal or nonverbal information" (2015: page 1). It can be added that a Learning Disability is a general word that details specific problems in the learning process that directly affect to people in their learning abilities, the most common affected abilities are; Listening, Writing, Speaking, Reading and also in others sciences of study like Maths, Chemistry.

Hancock (2009) points out that "Besides dyslexia, there are numerous types of learning disabilities that appear in school-aged children" (2009: page 1). In the same line, Learning RX (2009) says that "In addition to the cognitive processing categories, some types of learning disabilities are more specifically defined by education based labels such as reading, writing, language, and math" (2009: page 1). Some different learning disabilities are: 
- Dysgraphia: "The student has trouble reading written words fluently, out loud" (Learning RX, 2009: page 1). This disability is the result of Dyslexia which lacks the motor coordination and it causes problems in order to understand the space, therefore, it can be said that this incapacity affects the writing skill.

- Dyscalculia: "The student struggles with math problems and concepts" (Learning RX, 2009: page 1). Dyscalculia is considered as a disability that affects to the learning mathematics process.

- Dyspraxia: "It is considered as a motor condition disability" (Learning RX, 2009: page 1). When it is spoken of Dyspraxia it directly makes reference to the problems or the inability of a person to perform moves in the right way, it is difficult for to be concentrated in order to make a good and coordinate movement.

- Aphasia: "The student has difficulty understanding spoken language" (Learning RX, 2009: page 1). Aphasia is known as a disorder caused by damage to certain areas of the human brain that affects not only the language but also writing, reading and in many cases, it makes difficult expressing something that people want to say.

- Central Auditory Processing Disorder: "A sensor disability related to processing sounds" (Learning RX, 2009: page 1). This kind of disability makes people in this case scholars cannot recognize the different words' sounds making difficult for them to understand and process what people are talking about.

- Visual Processing Disorder: "A sensor disability related to processing images" (Learning RX, 2009: page 1). This class of inability as his name indicates, affects to the humans' eyes but this does not mean that people cannot see but it does not allow that the person cannot distinguish some images from other groups or by color for example, etc.

- Dyslexia: Borton (2014) asserts that "Dyslexia is an inherited condition that makes it extremely difficult to read, write, and spell in your native language despite at least average intelligence" (2014: page 1). In line with this, it can be added that Dyslexia is the most common disability that affects the language specifically to the reading in children making difficult for them to have a good comprehension of it and it is usually associated with Dysgraphia and it is due to have problems with the writing skill. If a person has Dyslexia it does not mean that he has a low grade of intelligence and it is due to the fact that it is independently of factors like cultural, emotional or intellectual, often this class of disability is transmitted in genetic form.

On the other hand Kemp, Smith and Segal (2015) say that "Reading comprehension problems occurs when there is an inability to grasp the meaning of words, phrases, and paragraphs" (2015: page 1). With the previously mentioned, it can be exposed that Dyslexia involves a lot of things that must be developed and enhanced with urgency in order to improve reading comprehension in students. Talking about educational field, usually school institutions do not provide a good learning environment for learners with Dyslexia, more than this; those students sometimes are not part of the classroom even when they are in class.

In the same way, Johnson (2013) says that "Armed with an understanding of this distinction, we parents can speed less time in fruitless battles with schools and more time on the important work of helping children get the assistance they need from all sources" (2013: page 1). According to this, it can be added that the main barrier for children with Dyslexia are the schools, nowadays, in Ecuador there is a few institutions that are working with learners with learning disabilities.

Kovar (2009) points out the following "There are five quick strategies for increasing the reading comprehension; Pre-Reading predictions, Chunk Summaries, 3 step post reading review, Describe the reading to someone else and Make a mind-map" (2009: page 1). According to this, there are some 
strategies in order to help students in enhancing their reading comprehension and it is necessary to be familiar with these kinds of strategies, therefore it will take five of them as examples.

- Pre-Reading Predictions: This type of activity allows students to make an explanation and an increment of their knowledge and previous experiences according to the subject that they are going to read. It also allows learners to know the vocabulary or the terms in order to make a good understanding of the text. In addition, this activity stimulates the predictions about the text, making easy and reasonable the reading goals. Chunk states that this activity consists that a student makes a summary of each paragraph, which consists of doing one or two sentences about each paragraph but each of these summaries must be written in their own words. Once the student has made the summary of all reading paragraphs, the student must do a summary of all summaries, if the activity is in group, learners can compare the summary with their classmates in order to make a better understanding of the extra that will be read.

- Post Reading: The student must divide the reading in three steps which in first place the learner has to write about the authors ideas, as a help the student can use the written summaries used in the Chunk Summaries activity, with the use of this activity, the reader will understand the written message by the author. Then as a second step, the student must write the importance of the text for the author and for the reader then the learner must do a comparison between both. Finally, the student must determine how the text is structured.

- Describe the reading to someone else: The learner must detail what he has read what using his own ideas or words, in fact he can describe what he has read to his family in order to practice his reading comprehension but he must use an appropriate language in order to make easy including a good understanding for the listener. The main idea of this activity is to help students in describing how the text had an impact in his life if that were the case.

- Make a mind-map: It is considered one of the best techniques for improving the reading comprehension. In this activity the student must put all his thoughts, summaries and his appreciations about the text that he has read in a comprehensible graphic, but it is not necessary that the student writes all the reading information, by the contrary, he must write few words or main ideas in order to connect or make a relationship with the other graphics making easy for him at the moment of speaking or explain his ideas with the rest of the class.

According to Guidelines for easy-to-read materials (International Federation of Library Association and Institutions, 2010) there are two slightly different definitions of the term "easy-to read". One means a linguistic adaptation of a text that makes it easier to read than the average text but which does not make it easier to comprehend; the other definition means an adaptation that makes both reading and comprehension easier. To achieve such a product, the writer/publisher must take into consideration content, language, illustrations, as well as graphic layout. These stories are designed considering the age of the students and are created to put in practice a particular reading strategy, such as compare and contrast, sequence of events, story structure, among others. These texts are designed to catch the reader's attention and to motivate them with focalized stories and pictures. Using these types of readings, students can concentrate in one strategy at a time and can be directed by the teacher in order to develop them properly.

As it is mentioned in different Learning Theories, the human mind naturally organizes and stores information, consequently our minds create structures to store newly acquired information and connect it to previous knowledge. The graphic organizers are visualizations of these mental storage systems, and serve to support students in remembering and connecting information. Through the graphic organizers learners can arrange, compare and connect the information for a better comprehension, so that graphic organizers are considered as effective pedagogical tools for organizing contents and ideas that will facilitate learner's comprehension. The use of the Mind Map Technique as a post reading strategy will support students to consolidate their ideas in a graphic organizer to internalize what they are understanding during the process. 
This educational project is based and directed on this kind of learning disability because is very familiar to find children with this problem during their scholar age, where is a real challenge to carry on with this difficulty and for this reason there is a need of helping learners with their learning disabilities in order to provide them an education of quality accompanied by an excellent environment.

\section{Methodology}

The principal aim was to find the reality of the education as well as the importance of the topic, that is why different mechanisms for evaluation were used. The instruments were: a survey, an interview and observation guide.

This research study is set in the qualitative and quantitative mode of a feasible project which will take theoretical principles and it will be able to materialize in a mediate period as long as the procedures allow implementing the necessary resources to develop and change. It was developed using the logic of research from the theoretical support of the variables until the interpretative processes as well as the quantitative data got from tabulations of the survey and interviews.

\subsection{Theoretical methods}

The authors of this project applied the qualitative and quantitative methods in the process of collecting information. In the qualitative method the authors examined the general nature of the problem which provided them a lot of valuable information and this method also contributed to identify the main factors that were measured in breadth and depth which help to them in order to explain the behavior of the problem. Wyse (2011) indicates that "Qualitative method is used to gain an understanding of underlying reasons, opinions, and motivation. Qualitative research is also used to uncover trends in though and opinions, and dive deeper into the problem" (2011: page 1). In the Quantitative Method: they collected data which comes from a calculation or measurement of a determined categories or elements in order to check an existing theory putting them in a numerical or statistical form.

\subsection{Empirical methods}

The investigators applied empirical instruments starting with the Observation, which permits identify and adapt the information found in the chosen context in order to work with specific facts through a physical document as the observation form. Document that has a structured type that shows the most important points of this research. The interview for data collection through a professional dialogue for acquiring information about what is being investigated. The survey includes the name, gender and course of the students who were surveyed, information that will help to determine the age when the disability is detected or if its presence is more in boys or in girls.

\subsection{Mathematical and statistical method}

This method helps to collect statistical information, which is explained in tables and graphs that show the difficulties and strengths accordance with each measure. And they also demonstrate the relation between the two variables studied; dependable variable about graphic organizers and the undependable variable focused on reading comprehension

\section{Results}

The Observation Sheet of Class bellow (see Table 1) was applied to basic elementary courses of three different high schools, with a total population of ninety-two students and includes sixteen statements about motivation before and during a reading class, about students and the pedagogical skills of teachers to work with differentiate students. 


\begin{tabular}{|c|c|c|c|c|c|}
\hline \multicolumn{6}{|l|}{ Observation sheet of class } \\
\hline \multicolumn{6}{|l|}{ Date: } \\
\hline \multicolumn{6}{|l|}{ Course: } \\
\hline \multicolumn{6}{|l|}{ Content: } \\
\hline \multicolumn{6}{|l|}{ Objective: } \\
\hline \multicolumn{6}{|l|}{ References: $1=$ excellent $2=$ suitable $3=$ moderately suitable $4=$ suitable little $5=$ not possible to observe } \\
\hline About the motivation class before reading & 1 & 2 & 3 & 4 & 5 \\
\hline \multicolumn{6}{|l|}{ 1. The introduction to the class is related to the proposed topic } \\
\hline \multicolumn{6}{|l|}{ 2. Perform a probe of prior knowledge on the subject to be treated } \\
\hline \multicolumn{6}{|l|}{ 3. He/She shows creativity in the creation of the initial activity } \\
\hline \multicolumn{6}{|l|}{ 4. Transmit enthusiasm and interest } \\
\hline \multicolumn{6}{|l|}{ 5. The resources are properly used } \\
\hline \multicolumn{6}{|l|}{ During the class } \\
\hline \multicolumn{6}{|l|}{ 1. The teacher explains the themes clearly } \\
\hline \multicolumn{6}{|l|}{ 2. Promotes the student participation and verifies their comprehension } \\
\hline \multicolumn{6}{|l|}{ 3. Encourages students to work in different activities for reading comprehension } \\
\hline \multicolumn{6}{|l|}{ 4. Works with extra materials } \\
\hline \multicolumn{6}{|l|}{ 5. Explains the main idea of the reading } \\
\hline \multicolumn{6}{|l|}{ About the students } \\
\hline \multicolumn{6}{|l|}{ 1. Demostrate understanding while they are reading } \\
\hline \multicolumn{6}{|l|}{ 2. Can synthesize principal ideas about the text } \\
\hline \multicolumn{6}{|l|}{ About the pedagogical skills of teachers } \\
\hline \multicolumn{6}{|l|}{ 1. Demonstrates an attitude of openness to students difficulties. } \\
\hline \multicolumn{6}{|l|}{ 2. Performs differentiate guideline objectives for students who show difficulties } \\
\hline \multicolumn{6}{|l|}{ 3. Promote the development of the reading skill } \\
\hline 4. Dominion of reading techniques & & & & & \\
\hline
\end{tabular}

Table 1. Observation Sheet of Class

Accordance with the Observation Sheet the teachers do not know the appropriate techniques to develop the Reading Skill in students with disabilities, they work using the same strategies and techniques all the students in the class.

The following interview (see Table 2) was applied personally during a visit to the English Coordinators of three high schools. We took note of their answers explaining the different difficulties they have to manage with the students with learning difficulties. The objective is to determine the appropriate strategies in the development of reading comprehension of students with dyslexia.

Taking into account the answers in this interview the coordinator expresses how difficult is to help students with learning difficulties, especially with dyslexia, considering that the teachers are not trained to work with them and the collaboration of parents is not enough. Students can develop their abilities in a better way if the appropriate methodologies and techniques would be applied.

The survey below condensed the total population of ninety-two students of basic elementary (see Table 3) which was applied by the researchers to three different high schools in the north of the city of Guayaquil. The instrument includes ten statements focused in the comprehension of reading in English, so that students answer how they feel during the process.

The majority of students, between 11 and 14 years old, who attend the same school year but in different high schools answered the questionnaire that included ten statements about the difficulties to understand the main idea of a book in English is because they find new vocabulary or because teachers do not apply new methodologies in order to develop their reading comprehension.

Students were strongly agreed that the use of graphic organizers will benefit them to understand the information of the readings, because it is possible to divide it in different sections also it will help to classify and resume information paragraph by paragraph allowing them to relate each part. Through the 
Venn Diagram the information can be distributed into different parts including a relationship between them, in the case of reading it is separated by paragraph by paragraph, which will encourage students to obtain a better reading comprehension especially for students with any learning disability.

\begin{tabular}{|c|c|}
\hline \multicolumn{2}{|c|}{ Interview to the coordinator of the inclusive educational department } \\
\hline $\begin{array}{l}\text { 1. How many students with learning } \\
\text { disabilities are there in the High } \\
\text { School? }\end{array}$ & $\begin{array}{l}\text { There are fifteen students with learning disabilities in the basic in the } \\
\text { basic elementary section }\end{array}$ \\
\hline $\begin{array}{l}\text { 2. From students with learning } \\
\text { disabilities, how many of them have } \\
\text { dyslexia? }\end{array}$ & There are six students with dyslexia. \\
\hline $\begin{array}{l}\text { 3. What kind of pedagogical strategies } \\
\text { are applied to students with dyslexia? }\end{array}$ & $\begin{array}{l}\text { The pedagogical strategies applied to students with dyslexia are: having } \\
\text { them to put in order syllables to create, to repeat syllables, to complete } \\
\text { words in a statement, and so on. }\end{array}$ \\
\hline $\begin{array}{l}\text { 4. To reinforce the learning process at } \\
\text { home, what is the commitment for } \\
\text { the parents? }\end{array}$ & $\begin{array}{l}\text { The parents' commitment is to look for a specialist to put their children } \\
\text { in an adequate treatment to handle their difficulties in a better way }\end{array}$ \\
\hline $\begin{array}{l}\text { 5. What are the functions of the } \\
\text { teachers to face inclusive education? }\end{array}$ & $\begin{array}{l}\text { The functions of the teachers for facing inclusive education is to } \\
\text { elaborate adapted syllabus in order to give inclusive students a } \\
\text { curriculum suited for their abilities and levels. Also, to focus more on } \\
\text { these students while teaching the regular classes helping them to } \\
\text { emphasize in the syllabus us. }\end{array}$ \\
\hline $\begin{array}{l}\text { 6. Have the teachers had an adequate } \\
\text { training to teach students of the } \\
\text { inclusive educational program? }\end{array}$ & $\begin{array}{l}\text { No, teachers do not usually have training when performing their careers } \\
\text { to teach students of inclusive educational programs, not even in the } \\
\text { schools, because of that the inclusive educational department for the } \\
\text { school which provides them a brief guidance to execute adapted } \\
\text { curriculum for these students. However, this aid is not enough to help } \\
\text { students to develop their skills in their learning process }\end{array}$ \\
\hline $\begin{array}{l}\text { 7. If the answer to question } 6 \text { is yes, } \\
\text { what kind of training have the } \\
\text { teachers had? }\end{array}$ & The answer is not applicable for this question \\
\hline $\begin{array}{l}\text { 8. What tools do the teachers have to } \\
\text { develop reading comprehension } \\
\text { abilities of students with dyslexia? }\end{array}$ & $\begin{array}{l}\text { Teachers who give lessons of language in Spanish do have certain tools } \\
\text { to develop reading comprehension of students with dyslexia, but not as } \\
\text { many as it should be. But this does not include English classes; the } \\
\text { teachers only have the regular book, the board and the recorder to give } \\
\text { regular classes, which is not appropriate to reach the target that is } \\
\text { developing students' abilities to communicate in a foreign language. }\end{array}$ \\
\hline $\begin{array}{l}\text { 9. Do you think it is an advantage to } \\
\text { have a handbook with easy-to-read } \\
\text { stories with graphic organizers to } \\
\text { promote the reading comprehension } \\
\text { in students with dyslexia? Why? }\end{array}$ & $\begin{array}{l}\text { Yes, I think it would be a really helpful tool for English teachers to } \\
\text { promote the reading comprehension in students with dyslexia by using } \\
\text { and designing graphic organizers to have a better understanding of the } \\
\text { main ideas of the texts. Actually, the inclusive department of this } \\
\text { institution proposed a similar idea in Spanish for next school year, but } \\
\text { the project has not been done, hence I believe this handbook with } \\
\text { easy-to-read stories will be a useful and interesting instrument to } \\
\text { upgrade students' level and ability as English readers. }\end{array}$ \\
\hline
\end{tabular}

Table 2. Interview to the Coordinator of the Inclusive Educational Department

In order to relate de information obtained in the surveys the results were tabulated using the chi-square (see Table 4) which establishes the probabilities between the information:

As per the results of chi-square measure, the comparison between different statements about students survey was done and the results stablish the correlation and probability that represent the different values.

Most of learners accepted that the motivation in the design of graphic organizers enhances the foreign language learning, and they also indicated that this type of methodology makes more interesting to learn any subject. 


\section{Results of the survey for students}

\begin{tabular}{|c|c|c|c|c|c|}
\hline \multicolumn{6}{|c|}{$\begin{array}{l}\text { This survey is applied to students of eighth course who suffer Dyslex } \\
\text { of Guayaquil }\end{array}$} \\
\hline \multicolumn{6}{|c|}{ Age: __ Gender: _ Male - Female Course: _ $8^{\text {th }}$ Basic Elementary } \\
\hline & $\begin{array}{l}\text { Strongly } \\
\text { agree }\end{array}$ & Agree & Neutral & Disagree & $\begin{array}{l}\text { Strongly } \\
\text { disagree }\end{array}$ \\
\hline 1. Daily reading is important & $41 \%$ & $8 \%$ & $1 \%$ & & \\
\hline 2. I enjoy reading English texts and stories & $43 \%$ & $1 \%$ & $3 \%$ & $3 \%$ & \\
\hline $\begin{array}{l}\text { 3. It is difficult to understand the meaning of } \\
\text { an English book }\end{array}$ & $44 \%$ & $5 \%$ & & & $1 \%$ \\
\hline $\begin{array}{l}\text { 4. The principal reason when I do not } \\
\text { understand a text in English is because it } \\
\text { does not have graphic organizers. }\end{array}$ & $28 \%$ & $22 \%$ & & & \\
\hline $\begin{array}{l}\text { 5. Motivation in the design of graphic } \\
\text { organizers helps in the learning of a foreign } \\
\text { language }\end{array}$ & $45 \%$ & $5 \%$ & & & \\
\hline $\begin{array}{l}\text { 6. The application of graphic organizers as } \\
\text { the Venn Diagram help to get a better } \\
\text { reading comprehension. }\end{array}$ & $35 \%$ & $15 \%$ & & & \\
\hline $\begin{array}{l}\text { 7. The graphic organizers are commonly used } \\
\text { in English reading. }\end{array}$ & & & & $7 \%$ & $43 \%$ \\
\hline $\begin{array}{l}\text { 8. The use of graphic organizers helps to get } \\
\text { a better comprehension about a specific } \\
\text { topic in class. }\end{array}$ & $44 \%$ & $6 \%$ & & & \\
\hline $\begin{array}{l}\text { 9. The habit of applying a manual with } \\
\text { Reading techniques as easy-to-read } \\
\text { reinforce the English learning. }\end{array}$ & $44 \%$ & $5 \%$ & & $1 \%$ & \\
\hline $\begin{array}{l}\text { 10. The handbook with easy-to-read stories is a } \\
\text { didactic material that will guide the learning } \\
\text { of English as a foreign language. }\end{array}$ & $40 \%$ & $6 \%$ & $3 \%$ & $1 \%$ & \\
\hline
\end{tabular}

Table 3. Results of the Survey for Students

\begin{tabular}{|l|r|r|r|r|r|}
\hline \multicolumn{2}{|c|}{ Chi-square test } \\
\hline & \multicolumn{1}{|c|}{ Value } & \multicolumn{1}{c|}{ Df } & \multicolumn{1}{c|}{$\begin{array}{c}\text { Asymp. Sig. } \\
\text { (2-sided) }\end{array}$} & $\begin{array}{c}\text { Exact Sig. } \\
\text { (2-sided) }\end{array}$ & $\begin{array}{c}\text { Exact Sig. } \\
\text { (1-sided) }\end{array}$ \\
\hline Pearson Chi-Square & 5.009 & 1 & .025 & .033 & .025 \\
\hline Correction of Continuityb & 3.714 & 1 & .054 & .033 & .025 \\
\hline Relation of Probability & 5.318 & 1 & .021 & .033 & .025 \\
\hline Fishers exact exam & & & & .027 & .025 \\
\hline Linear-by-Linear Associate & 4.909 & 1 & & & \\
\hline $\mathrm{N}^{\circ}$ of valid cases & 50 & & & & \\
\hline
\end{tabular}

Table 4. Chi-Square Test

\section{Conclusions}

After applying the Observation sheet, it was determined the lack of attention to work with students with learning difficulties, as well as the deficiency of preparation of teachers to manage this kind of students. As they do not know how to work with them, they assume the students comprehension is equal for all of them.

The interview that was carried out for different coordinators, who are prepared to attend students with difficulties but their disadvantage is that they do not teach English or they cannot be working with the students one by one. Coordinators accepted the difficulty they are facing with students with disabilities and the best they did was trying to train teachers offering brief seminars, which is not enough to solve the problem. 
On the other hand, the students who were surveyed confirmed their misunderstanding or the total lack of comprehension when they are reading in English. They also agree that the application of new techniques specific and especial for them would motivate and clear up their doubts while they are reading English texts.

Each one of the results of the answers about the statements were tabulated, analyzed and placed in tables with the respective percentage per each option and they were also represented in statistical graphs as spherical figures to demonstrate the maximum score for an option and the minimum score for another option about the same statement. Statistical graphs support to identify the tendency in each answer.

The evaluation of the results about the different mechanisms that were applied, help to determine that the use of appropriate methodology and techniques including the adequate and suitable didactic material for the English teachers will be a great benefit because they will improve the quality of education to the learners, especially for students who present learning disabilities like dyslexia, dysgraphia, dyscalculia, etc.

The different activities using organizers of ideas are specifically designed to develop comprehension of the content students are reading. It also will stimulate students with dyslexia to be integrated, participative in the class because they are involved with the content of the readings.

After reviewing the answers of the members of the educative community who were surveyed we conclude that using graphic organizers in class help to have a better comprehension of a specific topic in the classroom for students with learning difficulties.

\section{Declaration of Conflicting Interests}

The authors declared no potential conflicts of interest with respect to the research, authorship, and/or publication of this article.

\section{Funding}

The authors received no financial support for the research, authorship, and/or publication of this article.

\section{References}

Borton, S. (2014). What is Dyslexia? Bright Solution for Dyslexia. http://www.dys-add.com/dyslexia.html (Accessed: August 2017)

Cain, K. \& Oakhill, J. (2004). Reading Comprehension Strategies: Theories, Interventions and Technologies Retrieved: March 7, 2018. https://books.google.com.ec/books?hl=en\&lr=\&id=Xj5HEdLGgYC\&oi=fnd\&pg $=$ PA47\&ots $=$ ANJXpBgc5$\underline{\& s i g}=$ Yp $5 \mathrm{hGVziQRyIy}$ Szs5TxQN isNRc\&redir esc $=\mathrm{v} \# \mathrm{v}={ }_{\text {onepage\& }} \& \mathrm{ff}=$ false

Hancock, M. (2009). Types of Learning Disabilities. Understanding Special Education. http://www.understandingspecialeducation.com/types-of-learningdisabilities (Accessed: August 2017)

International Federation of Library Association and Institutions (2010). Guidelines for easy-to-read materials. IFL A Professional Reports, 120. Available at:

https://www.ifla.org/files/assets/hq/publications/professional-report/120.pdf (Accessed: January 2018)

Johnson, A. M. (2013). Why Won't My School Treat Dyslexia? The Dyslexia Center of Princeton. http://www.dyslexiaprinceton.org/school.php (Accessed: April 2017)

Kemp, G, Smith, M., \& Segal, J. (2015). Helping Children with Learning Disabilities. Help Guide. http://www.helpguide.org/articles/learning-disabilities/helping-children-with-learning-disabilities.htm (Accessed: March 2017) 
Kemp, G, Smith, M., \& Segal, J. (2017). Learning Disabilities and Disorders - Types of Learning Disorders and Their Signs. Help Guide. https://www.helpguide.org/articles/autism-learning-disabilities/learning-disabilitiesand-disorders.htm (Accessed: December 2017)

Kovar, V. (2009). 5 Ways to Improve Reading Comprehension. Pick the Brain Grow Yourself. http://www.pickthebrain.com/blog/5-waysto-improve-reading-comprehension/ (Accessed: April 2017)

LDAC. (2015). Official Definition of Learning Disabilities. Learning Disabilities Association of Canada. http://www.ldacacta.ca/learn-more/ld-defined/official-definition-of-learning-disabilities (Accessed: October 2017)

Learning RX. (2009). Types of Learning Disabilities. Learning Rx. One-on-one brain training. https://www.learningrx.com/some-types-of-learning-disabilities.htm (Accessed: November 2017)

Wyse, S.E. (2011). What is the Difference between Qualitative Research and Quantitative Research? Snap Surveys. http://www.snapsurveys.com/blog/what-is-the-difference-between-qualitative-research-and-quantitative-research (Accessed: January 2018)

Published by OmniaScience (www.omniascience.com)

Journal of Technology and Science Education, 2018 (www.jotse.org)

\section{(c) (1) \$}

Article's contents are provided on an Attribution-Non Commercial 4.0 Creative commons International License. Readers are allowed to copy, distribute and communicate article's contents, provided the author's and JOTSE journal's names are included. It must not be used for commercial purposes. To see the complete licence contents, please visit https://creativecommons.org/licenses/by-nc/4.0/. 